\title{
NEW GENERIC NAMES AND NEW SPECIES OF MARINE MOLLUSCA.
}

By Tom Iredale.

Read 10th May, 1912.

PLATE IX.

To this periodical I have already contributed papers originated through the study of a collection of shells made at the Kermadec Islands, and in this essay I describe a few of the novelties there obtained, and also propose some new generic names. The determination and description $f$ new specific forms is a necessary evil, but the attempt to generically place even common shells seems to be an unnecessary evil to the majority of writers, and one which has been constantly neglected. I noted (this periodical, vol. ix, p. 70): "Furthermore I have found great difficulty in generically locating such well-known species as Drupa(?) chaidea, Duclos, and Galeropsis(?) monodonta, Quoy \& Gaimard." Prolonged study has convinced me of the inaccuracy of the continued attachment of the preceding, with others, to genera with which they have little in common, and I later wrote (vol. ix, p. 320): "In recent years scarcely any scientific worker has described a new minute shell without carefully detailing the apical characters, and using them for classificatory purposes. Yet these same workers have been content to class larger well-known shells in an almost Linnean fashion."

In attempting to work through this collection I have been impressed with factors that have militated against the accurate and easy determination of the Indo-Pacific Marine Mollusca: firstly, the lack of series, showing variation, from almost any locality, and especially the almost entire absence of individuals showing the juvenile characters: this is most noticeable when it is realized that the majority of the common littoral Indo-Pacific molluses are so abundant that long series of many forms could be easily obtained in a single day, covering most stages from the very young to adult. We are thus ignorant of the juvenile stages of very many of the commonest molluscs, and know the development only in rare cases, and until such are fully known all our higher groupings must be most imperfect, and in many cases also inaccurate. Secondly, it is no longer a possibility to correctly work out such a collection as mine without practically monographing each genus, more certainly as the monographs in the earlier volumes of Tryon's Manual of Conchology are useful only as works of reference to literature, the malacological matter being quite unreliable. I am convinced that all future workers, to produce any lasting results, must undertake monographic studies, and moreover must study series, note variation, also determine the sub-species from such series, and discriminate between species, sub-species, and varieties. I foresee the time when there will be more genera, fewer species, and more sub-species, with entire elimination of varieties. These latter may interest non-scientific 
workers, but serious students should never name such. Unfortunately, though I have, in the majority of cases, long series from the Kermadecs, the previously named molluses with which comparisons have been instituted are represented by odd specimens only.

Since this note was written my views have received quite unexpected confirmation by the study of series of Janthina.

\section{RoYa, n.gen.}

\section{Roya Kermadecensis, n.sp. Pl. IX, Fig. 10.}

Shell thin, conical, bilaterally symmetrical, broadly ovate, anterior slope long, arched, posterior slope steep, scarcely concave. Apex at about four-fifths its length, nucleus anastrophic, almost immersed by last whorl. The muscular impression is horseshoe-shaped, symmetrical, but composed of two portions : a semicircular broad scar ending in an enlargement, and then on each side continued by a narrow line; these lines meet obliquely-set oval scars, which are connected by a narrow line. This muscular impression is invisible in dead shells, which are translucent. These are pale rufous, sometimes rayed with a darker colour; there is no apparent sculpture save growth-lines. The live shell is clothed with a fine green epidermis. Length about $5 \cdot 5$, breadth $3 \cdot 5$, height $3 \mathrm{~mm}$.

Radula: Like that of Gena (Gwatkin).

Hab.-Sunday Island, Kermadec Group.

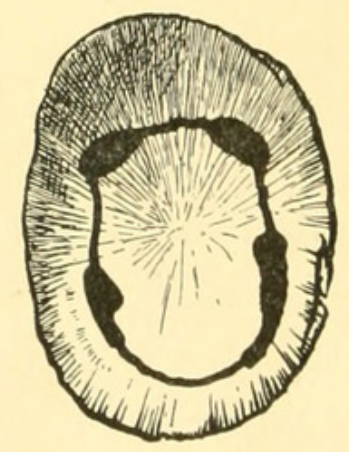

Externally this shell agrees very well with Capulus nutatus, Hedley (Proc. Linn. Soc. N.S.W., vol. xxxiii, p. 467, pl. ix, figs. 15-16, 1908). Upon comparison with the type of that species Mr. Hedley and I agreed it was inseparable as far as external conchological characters were observed. The muscle-impression of the shell, and the animal of $C$. nutatus are yet unknown. In the British Museum is the type of Tectura radiata, Pease (Proc. Zool. Soc. Lond., 1860, p. 437) from the Sandwich Islands. This seems to be another species of this genus. Yet this shell was at one time accepted as identical with Williamia Gussoni, Costa, by such an authority as Mr. E. A. Smith (Proc. Zool. Soc. Lond., 1890, p. 296), judging from conchological features alone. But $W$. Gussoni, Costa, belongs to the Siphonariidæ, whilst my shell does not. I am therefore doubtful of the correctness of merging specifically my shell with Capulus nutatus, Hedley, in view of the fact that animals of similar shells have proved 

Proc. Malac. Soc.

Vol. X, PI. IX.
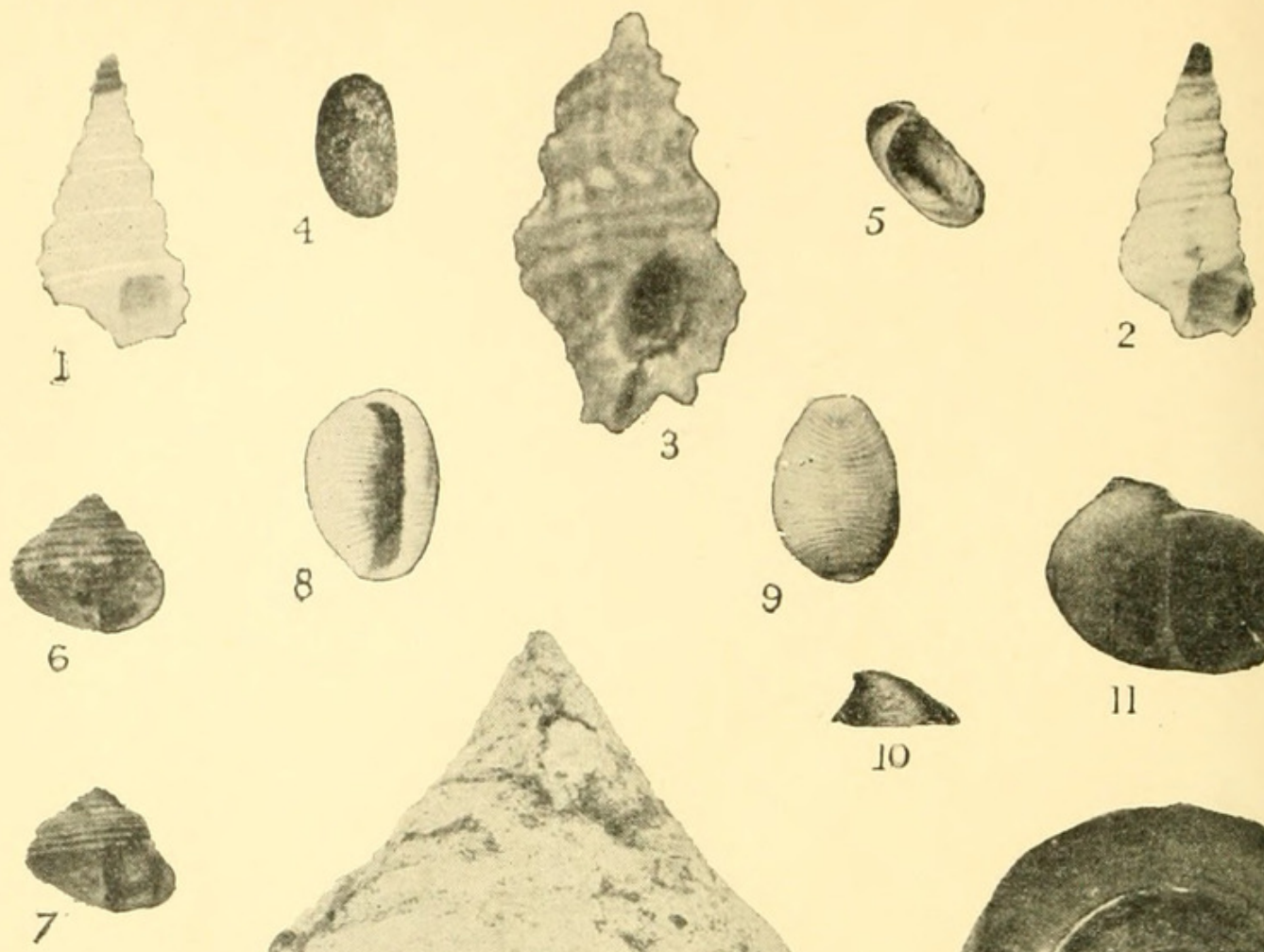

3
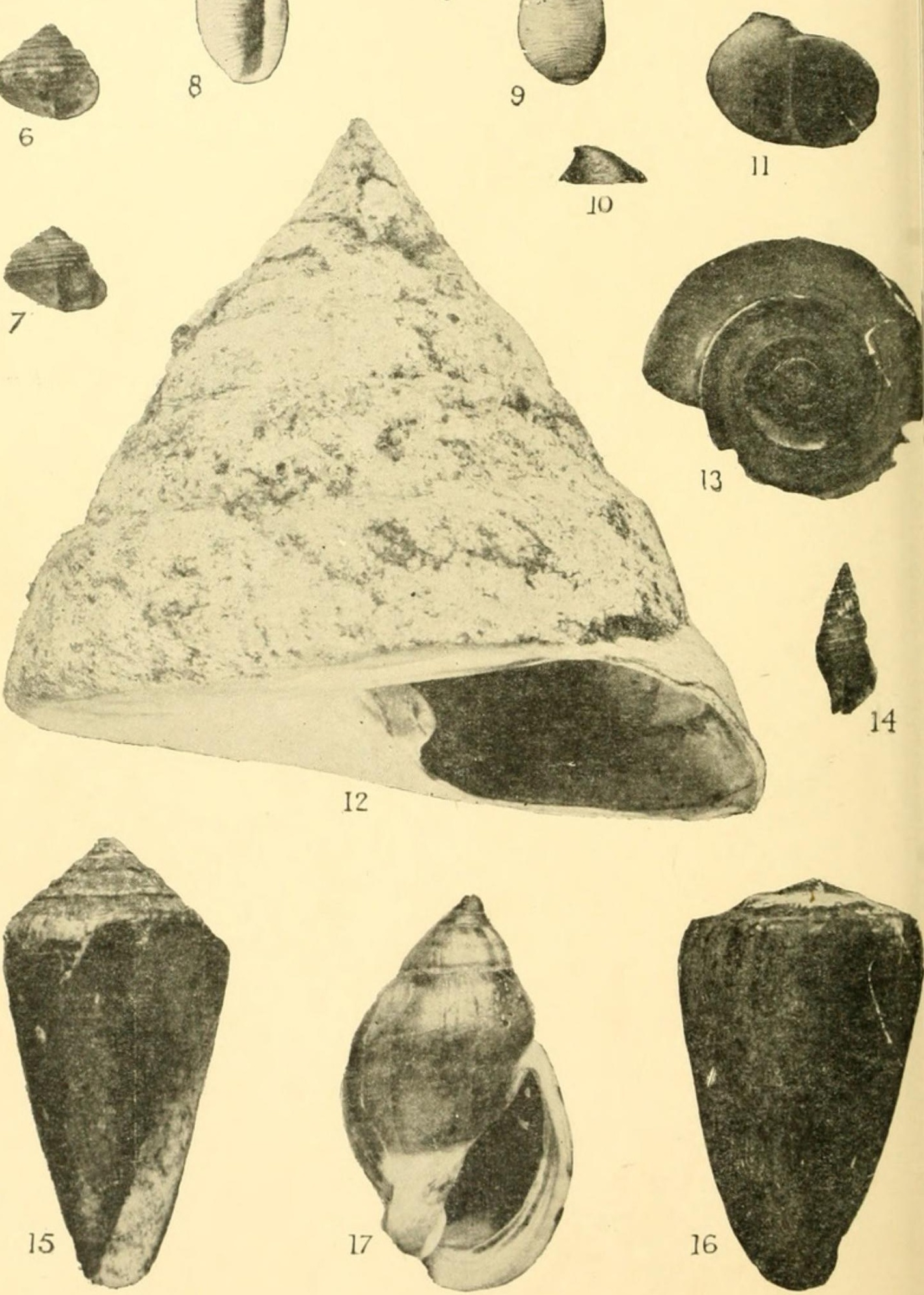

MOLLUSCA FROM THE KERMADEC ISLANDS. 
so very different, and I have therefore taken the extreme course of differentiating the Kermadec shell, until the muscle-impressions of C. nutatus are made known. This, moreorer, appears to be necessary, as my generic characters depend upon the animal and muscleimpressions, and I could not accurately name, as type, a shell in which they are not known to exist. Probably this is the shell recorded by Melvill \& Standen (Journ. Conch., vol. viii, p. 414, 1897) from Lifu, as Williamia radiata, Pease, which they placed in the family Acmæidæ !!

This and the following genus are named in honour of my friend Mr. Roy Bell, whose aid in investigating the Kermadec Mollusca I wish to commemorate.

\section{Royella, n.gen. Pl. IX, Figs. 1, 2.}

I propose this generic name for the shell described as Cerithium clathratum by Sowerby in the Thes. Conch., vol. ii, p. 883, pl. 185, fig. 258, 1855, from the Island of Bohol, and whose name was changed to $C$. sinon (Fig. 1) by Bayle in the Journ. de Conch., vol. xxviii, p. 243, 1880. When recorded from Lifu by Melvill \& Standen (Journ. Conch., vol. viii, p. 116, 1895), it was transferred to Cerithiopsis. When I noted its history as above in these Proceedings, vol. ix, p. 320, I obserred: "I don't know where to generically locate this shell, but it is certainly neither a Cerithium nor a Cerithiopsis." Further research has shown its distinctness from previously described generic forms, so I have been compelled to erect a genus for its reception. I might add I have seen other forms which appear to be congeneric. (Fig. 2, species undescribed.)

The shell is long, narrow, many-whorled, and tuberculate; apex long, sinusigeral, and pink, whilst the main shell is white; aperture circular, with a short distinct recurved canal. Operculum horny, multispiral; nucleus central.

The operculum of Cerithiopsis is said to be "paucispiral, somewhat concave, with three or four whorls, rather translucent and smooth outside" (Dall, Bull. Mus. Comp. Zool., vol. xviii, p. 252, 1889), whilst that of Bittium agrees better with this, but the shell characters at once separate Royella from Bittium. The shells usually assigned to Cerithiopsis and Bittium are of diverse generic types, and may be separated by means of the characters of their apices. I would recognize Joculator, Hedley, as fully worthy of generic rank, not accepting the conservative view taken by its author.

\section{BRоокULA, n.gen.}

In the Trans. New Zeal. Inst., vol. xl, p. 382, 1907 (1908), I recorded as recent a shell described from the Pliocene as Scalaria corulum by Hutton (op. cit., vol. xvii, p. 322, 1884 (1885)), and concluded: "Having carefully compared specimens, there is no doubt it is congeneric with Cyclostrema angeli, Ten.-Woods, and for the present the best location is in the genus Cyclostrema."

Since then I have examined quite a number of species which are congeneric; some were described as Rissoa, others as Scala or 
Scalaria, and most as Cyclostrema. The first two genera being generally abandoned, the last proves to be quite as unsuitable. Miss K. Bush, in the Trans. Conn. Acad., vol. x, pp. 97 et seq., 1897, published a Revision of the Cyclostrematids and allied genera, and, though she introduced several new genera, these species cannot be accurately placed in any. I therefore propose the genus Brookula, and name as type the following new species, $B$. stibarochila.

\section{Brookdla stibarochila, n.sp.}

Shell minute, globosely turbinate, perforate, glassy, transparent. Whorls four. First whorl and a half unsculptured, the succeeding whorls bearing sloping axial laminæ, the interstices crossed with fine regular striæ. On the last whorl fifteen lamellæ are present, the last forming the outer edge of the aperture. Aperture circular, continuous. Umbilicus narrow and deep.

Measurement of type: Height $1 \cdot 25$, breadth $1 \mathrm{~mm}$.

Hab.-Sunday Island, Kermadec Group.

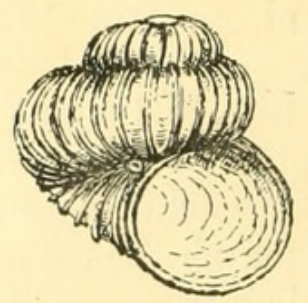

To this genus I would refer Cyclostrema conicum, Watson (Chall. Reports, Zool., vol. xv, p. 122, pl. viii, figs. 9a-c); angeli, T.-Woods; corulum, Hutton; crebrisculptum, Tate; denselaminatum, Verco; Nepeanensis, Gatliff, etc.

The genus is named after Mr. W. R. Brook Oliver, my collecting companion for many years, and one of the members of the Kermadec Islands Expedition.

\section{Jeannea, n.gen.}

Shell fusiform, the spire equalling the aperture in length; aperture oval; columella smooth; outer lip thick, but not denticled; canal short, recurved. Protoconch turbinate, two-whorled, unsculptured. Operculum leaf-shaped, nucleus apical.

Type, J. Hedleyi, n.sp.

\section{Jeannea Hedleyi, n.sp. Pl. IX, Fig. 14.}

Shell small, fusiform, solid. Characters as above. Adult whorls five. Colour reddish-fawn with darker markings. Sculpture commences with longitudinal ribs, which are well marked on the first two whorls and fade away subsequently, not showing at all on the last whorl. Spiral threads commence at the same time, but these persist throughout, the last whorl showing two major ones above the aperture, and seven equally spaced can be counted on the outer lip. Between these are minor threads; on the last whorl three being seen between each major thread. In some shells these are faintly nodulous, 
and the higher two major threads are farther apart, and between them are five to eight minor threads.

Measurements of type: Length 12 , breadth $5 \mathrm{~mm}$.

Hab.-Sunday Island, Kermadec Group.

The animal examined alive was of a white colour; eyes sessile as black specks; propodium square, whilst the radular characters are such that it might be referable to Cantharus or Pisania.

\section{Quoyula, n.gen.}

This is introduced for the shell described by Quoy \& Gaimard as Purpura monodonta (Voy. de l'Astrol. Zool., vol. ii, p. 561, pl. xxxvii, figs. 9, 10, 1833) from Tongatabu. I have given the history of its wanderings from Coralliophila through Rhizochilus and Galeropsis back to Coralliophila (these Proceedings, vol. ix, p. 76, 1910). I was inclined to let it stay in Coralliophila through the prejudice of the Sinusigera apex, but study of this shell with the other forms assigned to that genus has convinced me of the impropriety of so doing, and the only course open is to separate it.

Coralliophila was introduced by H. \& A. Adams in the Genera Recent Mollusca, vol. i, p. 135, 1853, as a sub-genus of Rhisochilus, and, though sixteen species were named as members of the genus, no type was selected. Dall (Bull. Mus. Comp. Zool. Harv., vol. xviii, p. 217,1889 ) noted this, and remarked that $C$. madreporarum could not be accepted as type, as it was not one of the original members of the sub-genus, but made no designation of type, adding " the true Coralliophila has been renamed Pseudomurex". Cossmann (Essais Paléoconch. comp., Livr. v, p. 83, 1903) has named as type "Purpura neritoidea, Lamk." In Adams' List is a "neritoideus, Chem.", so I would fix this as type. With this species I do not consider Quoy \& Gaimard's $P$. monodonta congeneric, neither do I now accept P. madreporarum, Sowerby (Gen. Rec. Fossil Shells, vol. ii, pl. 237, fig. 12, 1834) as conspecific with the latter. When looking up this I noticed a footnote reading, "Since the above was written Mr. Gray has separated the last-mentioned shells from Purpura, under the generic appellation of Pollia." This refers to the sentence "Triton undosus of Lam.: we suggest the probability of its forming a well distinguished genus in union with several other cognate species". In the British Museum copy of Sowerby's work Mr. Edgar A. Smith has noted that Pollia was not published by Gray until 1839 in the Zoology of Beechey's Voyage; this latter has generally been quoted as the first entrance of Pollia, whereas Sowerby's note has five years priority. Moreover, the type (by monotypy) of Pollia, Sowerby, 1834, is T. undosus, Lam., so that Tritonidea, Swainson, 1840 , would become an exact synonym, though probably both fall as equivalent to Cantharus, Bolten, 1798.

\section{Heterorissoa, n.gen.}

Shell minute, rissoid, smooth and shining, thin, glassy, transparent. Aperture broadly oval, peritreme thin, not continuous. Opereulum 
semilunar, horny, concentric, with a lateral nucleus: inner edge thickened, with an internal rib from the nucleus, but no projecting rib.

Type, Heterorissoa secunda, Iredale.

This genus apparently takes the place of Jeffreysia in the Southern Hemisphere; in shell characters it agrees very closely with that

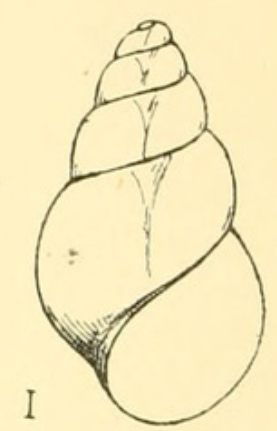

genus, but the operculum differs in lacking the projecting rib. The shell recently described as $J$. Wilfridi (Gatliff \& Gabriel, Proc. Roy. Soc. Vict., vol. xxiv, p. 188, pl. xlvi, fig. 3, 1911) I would consider to belong to my genus, also $J$. Edwardiensis, Watson (Chall. Rep. Zool., vol. xv, p. 584, pl. xliii, fig. 5, 1886), from Prince Edward Island.

\section{Thais, Bolten.}

In this Journal, vol. ix, p. 322, 1911, I indicated my interest in the generic treatment of the molluses formerly classed under Purpura, Bruguière, but now known by the name of Thais, Bolten. At that time I was unaware that the group had been recently discussed by Dall (Dep. Int. U.S. Geol. Surv., Prof. Paper No. 59, 1909), and it was therefore with much interest that I studied his results. I hope to more fully deal with the conclusions there arrived at, but would here give expression to some points whereon I consider amendment possible. Before proceeding further I would express my deep gratitude for the great work which Dr. Dall is still doing; putting on record valuable synthetic papers, whereby analysis is made possible to those who are not skilled in the more difficult task of synthesis.

I have already definitely concluded that the juvenile stages of molluses must be studied before generic groups can be considered stable. Though Dall has studied the animals, and found little variation, I do not find in his paper any notice having been taken of the earlier stages, and consequently in his treatment of the New Zealand and Australian Thaitids I find disagreement with my own studies.

Dall recognizes Lepsia, Hutton, proposed for Purpura haustrum, Martyn, as of sectional value, under the sub-genus Thais. The method of classing the Thaitids, as one genus only, I consider improper, and the four sub-genera seem absolutely artificial. The skeletal nature of Dall's system is most perplexing to the Austral student who finds no place for his most common friends. For instance, take the group 
I mentioned (loc. cit., p. 321) as converging round Thais succincta, Lam. The only name I know of as being based on any of those there mentioned is Agnewia, Ten.-Woods, proposed for Purpura tritoniformis, Blainville. This is included in the general synonymy of Thais by Dall, but of what section or sub-genus he considers it a synonym in particular I am unable to say. Consequently I do not know where Dall would place any of our Australian Thaitids, save T. haustrum, Martyn, and T. amygdala, Kiener. Having carefully examined all the names noted by Dall as referable to these Thaitid molluscs, I propose Lepsiella, n.gen., with type Purpura scobina, Quoy \& Gaimard, and Neothias, n.gen., with type Purpura Smithi, Brazier, and will fully discuss their relationships and status in another place.

\section{Melarhaphe, Menke.}

This would appear to be the generic name to be used for the Australian species grouped round Littorina mauritiana, Lamarck. In the Proc. Roy. Soc. Tasm., 1908 (1909), p. 56, W. L. Mav accepted Litorina, Menke, 1828, concluding that Férussac's introduction of Littorina was unrecognizable as being that of a nude name only. He acknowledged that this acceptation was due to Mr. Hedley's suggestion. My own interpretation of Férussac's proposal was that Littorina was legitimately introduced by that author, and, moreover, that the type of that genus was $L$. obtusata, Linné, as fixed by Rang (Man. Mollusques, 1829 , p. 185) under the name L. littoralis. I am glad to note that Dall (Dept. Int. U.S. Geol. Surv., Prof. Paper No. 59, 1909, p. 79) had anticipated me in arriving at the same conclusion. The type of Littorina is quite unlike the AustroNeozelanic shells known under that name, and the name to be used for those is Melarhaphe. Commonly quoted as of Mühlfeldt, this name was introduced into literature by Menke (Synops. meth. Moll., 1828, p. 23) thus: Paludina glabrata, Zgl. (Turbo carulescens, Lam., T. rupestris, Chabr., Melarhaphe glabrata, Mhlfld.). The first reference is also to a manuscript name, as the only publication of Ziegler's name is by Pfeiffer in the Nat. Deutsch. Land u. Sudw. Moll., part iii. p. 46, pl. viii, figs. 9-10, 1828. This shell has been identified as Littorina neritoides, Linn., of which Turbo carulescens, Lam., is also considered a synonym. When Quoy \& Gaimard described their Littorina Diemenensis (Voy. de l'Astrol. Zool., vol. iii, p. 479,1835 ) they compared it specifically with $L$. carulescens, Lamarck, so that there need be no hesitation in using Melarhaphe for such shells.

\section{Penion, Fischer.}

The Austro-Neozelanic marine molluscan group commonly referred to as Siphonalia must bear this generic name.

Siphonalia was introduced by A. Adams (Ann. Mag. Nat. Hist., ser. III, vol. xi, p. 202, 1863) for a number of Japanese shells, of which Buccinum cassidariaforme, Reeve, is the first species, and should be taken as type; the others are mostly congeneric with this. This shell 
has little relationship with the New Zealand 'Fusoid' shells, and Siphonalia cannot be used for the latter.

Tryon (Man. Conch., vol. iii, p. 135, pl. liv, fig. 355, 1881) described an Australian shell as Siphonalia maxima. This was transferred to Megalatractus by Kesteven (Mem. Austr. Mus., vol. iv, pp. 419 et seq., 1904), but Siphonalia maxima is absolutely congeneric with $S$. dilatata, Quoy \& Gaimard, and these should not be classed with Megalatractus. I will give full details confirming this conclusion in another place.

Kobelt introduced Austrofusus (Küster's Conch. Cab., 1881, p. 127) for a number of Fusoid shells, including the Austro-Neozelanic 'Siphonalia', but Fischer in the Manuel de Conch., 1884, p. 625, cited as example of Austrofusus (which he made a sub-genus of Siphonalia), S. alternata, Philippi, which was the second of Kobelt's list, the first being indeterminable. At the same time Fischer proposed Penion for Siphonalia dilatata, Quoy \& Gaimard. I would therefore fix S. alternata, Philippi, as type of Austrofusus, and this leaves Penion to be used for the Austro-Neozelanic forms, and I would here unhesitatingly place Siphonalia maxima, Tryon.

\section{Bembicium, Philippi.}

This name must be used for the genus of Australian molluses known by the name of Risella. One species was for some time included in the New Zealand List, but was expunged by Suter (Trans. New Zeal. Inst., vol. xxxviii, p. 325, 1905 (1906)), who, however, concluded it must still be retained as occurring in the Pliocene in New Zealand.

Risella has been generally quoted as of Gray, 1840, but that reference is to the Synops. Brit. Mus., where it only occurs as a nude name. The earliest introduction legitimately made by Gray appears to be in the Proc. Zool. Soc. Lond., 1847, p. 150, where we read: "Risella, Gray, 1840, 1844. Bembicium, Philippi, 1846. Trochus melanostomus."

The 1844 reference to Gray seems to be only another case of Synops. Brit. Mus., so that Bembicium, Philippi, 1846, has clearly priority over Risella, Grav, 1847. In the Zeitschr. für Malak., September, 1846 , p. 129 , Philippi introduced this genus and monographed the species. Herrmannsen (Ind. Gen. Malac., vol. i, p. 111, 1846) designated as type of Bembicium, Trochus melanostomus, so that Risella, Gray, becomes an absolute synonym. In his vol. ii, 1847. Herrmannsen included Risella as a name in the Synops. Brit. Mus., which he had not seen, and in his Supplement, p. 119, 1852, included it as published in the Proc. Zool. Soc. Lond., 1847, p. 150.

This correction has escaped the attention of Australian workers for two reasons: first, the inaccessibility of literature compels acceptance of many quotations without opportunity of verification, and the constant citation of Gray, Synops. Brit. Mus., 1840, by better situated workers, would arouse no suspicion that only the nude name there occurred; secondly, in the Manual of Conchology, vol. ix, 
where Risella is monographed, there is no mention of Bembicium, Philippi, to incite interest.

I might here point out that Cossman recently proposed a new genus, which he named Risellopsis (Havre Bull. Soc. Géol., vol. xxvii, p. 59,1907 (1908)), but that name had been previously selected by Kesteven (Rec. Austr. Mus., vol. ir, p. 319, 1902) for a New Zealand marine molluscan genus.

\section{Lora, Gistel.}

In the Bull. Mus. Comp. Zool., vol. xliii, p. 259, 1908, Dall details the history of the generic names Defrancia, Millet, 1827, and Clathurella, Carpenter, 1856, selecting for type of Millet's genus Defrancia pagoda, Millet, and accepting that as type of Clathurella, Carpenter. It has apparently been overlooked that Gistel (Naturg. Thierr. hoh. Schulen, 1848, p. ix) had introduced Lora as a new name for Defrancia, Millet, noting D. viridula, O. Fabr., as a typical species.

\section{Pachycheilus.}

In the Penny Cyclopedia, vol. xvii, p. 454, footnote, 1840, this name is introduced as a better name than Pachylabra, Swainson's substitute for Pachystoma, Guilding, preoccupied. This would seem to invalidate Lea's later Pachychilus.

\section{Trochus Royanus, n.sp. Pl. IX, Fig. 12.}

Shell pyramidal, large, massive, imperforate. Whorls more than twelve, subscalar, last whorl strongly keeled, base flat. Colour white. In adult specimens sculpture scarcely distinguishable, but on the last whorl can be noted a sculpture of nodules somewhat after the style of ornamentation seen on $T$. pyramis, Born, but much finer. Base smooth, save for growth-lines. Aperture quadrate, very oblique, the basal portion smooth inside; outer lip thin, and very fragile. Columella pearly, anteriorly terminating in a solid tubercle, and ascending with a semicircular sweep. Operculum thin, horny, multispiral, nucleus central ; size $32 \times 27 \mathrm{~mm}$.

Measurements of type: Height 84 , major diameter, $84 \mathrm{~mm}$.

Hab.-Sunday Island, Kermadec Group.

The type of Trochus, Linné, Syst. Nat., 10th ed., 1758, p. 756, I now designate as $T$. maculatus, since $T$. Niloticus does not occur there.

\section{Clanculus atypicus, n.sp. Pl. IX, Fig. 7.}

Shell small, depressedly globose, solid, umbilicate; periphery rounded, base flattened. Colour: dark greyish-brown, painted obliquely with yellow or fawn. Whorls six. Sculpture consists of fine spiral threads of varying strengths, about eighteen major ones on the last whorl. The preceding whorl shows six major threads only. The axial sculpture is represented by very fine close lines. Suture deep, channelled, bounded by a row of nodules. Aperture oblique, sub-quadrate, the outer lip slightly erenulate and recurved. Umbilicus deep, surrounded by a noduled callused rim, the callus extending to 
meet the outer lip. Columella obliquely inserted in the umbilicus, with a small nodule at each end. Operculum circular, horny, thin, multispiral, nucleus central.

Measurements of type: Height 8, major diameter $9 \mathrm{~mm}$.

Hab. - Sunday Island, Kermadec Group.

\section{Monilea incerta, n.sp. Pl. IX, Fig. 6.}

Shell small, turbinate, thin, umbilicate; whorls convex, gradually increasing, slightly flattened below the suture, last whorl rounded at the periphery. Colour: generally blackish-grey irregularly rayed with white. Whorls six, the first one and a half minute, unsculptured; the sculpture consists of spiral threads increasing in number and strength, the penultimate whorl having three major ones, the last five above the periphery ; between these run from one to three minor threads. The whole shell is overridden by very fine axial striæ. The base is sculptured with about twelve even-spaced ridges, similarly overridden. Umbilicus narrow, bounded by a thickened rib, only developed in the adult; inside white. Aperture sub-quadrate, outer lip thin. Columella ascending with a faint reflection, and higher again reflected, when a rib enters the umbilicus; connected with the outer lip by a slight callus. Operculum circular, multispiral, nucleus central, thin and horny.

Neasurement of type: Height 10, major diameter $9 \mathrm{~mm}$.

Hab.-Sunday Island, Kermadec Group.

\section{Gena Oliveri, n.sp. Pl. IX, Figs. 4, 5.}

Shell oblong ovate, small, thin, about twice as long as broad. Whorls four. Colour blackish-grey, more or less marbled with lighter grey and white. Sculpture consists of fine spiral grooves decussated by growth-lines, but the apex has two well-developed keels which are diagnostic. Columella arched.

Measurement of type: Height 9, length $11 \mathrm{~mm}$.

Hab.-Sunday Island, Kermadec Group.

\section{Vanikoro Wallacei, n.sp. Pl. IX, Fig. 11.}

Shell globose, thin, perforate, last whorl increasing and descending rapidly. Whorls four. Colour white. The first whorl and a half are elevated, unsculptured, the succeeding whorls bearing fine closely set wavy threads, which are crossed by minute crowded striæ, these last predominate on the last whorl, but the whole sculpture is very fine. Columella obliquely set, straight; umbilicus wide and deep, bounded by a crenulate rib, inside crinkled parallel to the columella ; aperture semicircular, outer lip thin. Operculum horny, paucispiral, thin, like that of a Melarhaphe. 'This does not agree with the description of the operculum of Vanikoro as given by H. \& A. Adams.

Measurement of type: height 4 , breadth $4.5 \mathrm{~mm}$.

Hab.-Sunday Island, Kermadec Group.

\section{Trivia desirabilis, n.sp. Pl. IX, Figs. 8, 9.}

Shell small, sub-oval, extremities slightly produced; white, strongly sculptured. Sculpture consisting of about thirty major 


\section{$2 \mathrm{BHL}$ Biodiversity Heritage Library}

1912. "New generic names and new species of marine mollusca." Proceedings of the Malacological Society of London 10, 217-228.

https://doi.org/10.1093/oxfordjournals.mollus.a063491.

View This Item Online: $\underline{\text { https://www.biodiversitylibrary.org/item/52423 }}$

DOI: https://doi.org/10.1093/oxfordjournals.mollus.a063491

Permalink: https://www.biodiversitylibrary.org/partpdf/50934

\section{Holding Institution}

Smithsonian Libraries

\section{Sponsored by}

Smithsonian

\section{Copyright \& Reuse}

Copyright Status: Public domain. The BHL considers that this work is no longer under copyright protection.

This document was created from content at the Biodiversity Heritage Library, the world's largest open access digital library for biodiversity literature and archives. Visit BHL at https://www.biodiversitylibrary.org. 